\title{
Role of anti-thyroid peroxidase antibodies in adverse pregnancy outcomes
}

\author{
Abhilasha Gupta, Nishat Wajdi*, Aruna Verma, Monika Kashyap Pal
}

Department of Obstetrics and Gynaecology, SVBP Hospital, LLRM Medical College, Meerut, Uttar Pradesh, India

Received: 29 June 2016

Accepted: 05 August 2016

\author{
*Correspondence: \\ Dr. Nishat Wajdi, \\ E-mail: n.wajdi7@gmail.com
}

Copyright: ( ) the author(s), publisher and licensee Medip Academy. This is an open-access article distributed under the terms of the Creative Commons Attribution Non-Commercial License, which permits unrestricted non-commercial use, distribution, and reproduction in any medium, provided the original work is properly cited.

\section{ABSTRACT}

Background: Because of the link of thyroid auto antibodies with various pregnancy related complications and antithyroid peroxidase antibody (TPO Ab) being most common of all of them, can be used as a surrogate marker for thyroid related adverse pregnancy outcomes. Hence, present study was designed to further elucidate any association of anti-TPO antibodies and serum thyroid stimulating hormone (TSH) levels with adverse pregnancy outcomes.

Methods: This observational study has been conducted in the department of obstetrics and gynaecology at L. L. R. M. Medical College, Meerut, Uttar Pradesh, India. Five hundred randomly selected peripartum women from 20 weeks onwards have been included and divided into two main groups, anti-TPO Ab positive (group B) and anti-TPO Ab negative (group A). Serum TSH was done only in group B. These two groups were compared for age of the patient, period of gestation, number of abortions, pregnancy outcome, maternal and fetal complications.

Results: Out of 500 women, $18.6 \%$ were anti-TPO Ab positive. Number of abortions $\geq 2$ was found in $18 \%$ and $8 \%$ in group B and A whereas preterm delivery was found in $50 \%$ and $17 \%$ in the two groups respectively. In group B, $48 \%$ had increased TSH.

Conclusions: Anti-TPO Ab presence was significantly associated with preterm deliveries, recurrent abortions, increased maternal and fetal complications.

Keywords: Anti-TPO Ab, TSH, Abortions

\section{INTRODUCTION}

The maternal physiological changes that occur in normal pregnancy induce complex endocrine and immune responses. Thyroid disorders especially those of autoimmune origin are common in women of reproductive age group and approximately $1 / 5^{\text {th }}$ of childbearing-age women are positive for the anti-thyroid peroxidase antibody (TPO-Ab) or anti-thyroglobulin antibody (TG-Ab). ${ }^{1,2}$

A number of recent population studies has been conducted which suggest pregnancies with thyroid disorders may have an increased risk of pregnancy complications, including preterm delivery, placental abruption, intrauterine death, recurrent miscarriages, intrauterine growth retardation (IUGR), pre-eclamptic toxaemia and abnormal neuropsychological development in offspring. ${ }^{3-8}$

There is evidence that thyroid autoimmunity is an important risk factor for miscarriage and preterm birth. ${ }^{9}$ The presence of thyroid auto antibodies is relatively common in women of reproductive age. In an unselected population of women, the prevalence ranges from $6 \%$ to $20 \%$ being even higher in women with a history of recurrent pregnancy loss, at around $17-33 \%$, and in women with a history of subfertility, at around 10$31 \% .^{9,10}$ Because of the link of thyroid auto antibodies with continuing progression to incipient and then overt thyroid failure, it seems reasonable that such antibodies might be a surrogate marker for thyroid-related adverse pregnancy outcomes. 
This study has been aimed to study the prevalence of anti-TPO $\mathrm{Ab}$ in peripartum period in reproductive age group women and to correlate its presence with adverse pregnancy outcomes.

\section{METHODS}

This observational study was conducted at department of obstetrics and gynaecology, LLRM Medical College, Meerut during $1^{\text {st }}$ June $2014-31^{\text {st }}$ May 2015 after ethical clearance from institutional ethical committee. It was a cross-sectional or prevalence study design. 500 randomly selected peripartum women between ages 20 to 35 years from 20 weeks onwards were included; all patients underwent a comprehensive medical evaluation including a detailed history and a thorough physical examination. Women with known autoimmune disorders, already on treatment for thyroid dysfunction, history of cervical incompetence or any uterine pathology, patient suffering from any chronic systemic illness or any critical medical illness during pregnancy were excluded from the study.

$3 \mathrm{ml}$ venous blood collected in vacutainer. Each blood sample analyzed for anti-TPO levels by electrochemilumeniscence immunoassay (ELECSYS-2010, normal value $<9 \mathrm{IU} / \mathrm{ml})$. On the basis of anti-TPO antibody positivity, cases were divided into two groups, group A which was anti-TPO antibody negative and group B which was anti-TPO antibody positive. Serum thyroid stimulating hormone (TSH) was done in those who were anti-TPO antibody positive, (reference range first trimester $0.1-2.5 \mathrm{mIU} / \mathrm{L}$, second trimester $0.2-3$ $\mathrm{mIU} / \mathrm{L}$, and third trimester 0.3-3 mIU/L).

Data was recorded in a predesigned proforma and maternal and fetal outcomes were noted and compared in both the groups.

\section{Statistical analysis}

The sample size for a study of prevalence was calculated to an accuracy of $95 \%$ (5\% error), assuming a prevalence estimate of $10 \%$ (prevalence internationally reported), with a confidence level of $95 \%$ (5\% alpha error), yielding a sample size of 477 women. Unpaired t test was used for normal data and Mann-Whitney U test was used for nonnormal data. To analyze the dichotomous data, odds ratio or Fisher's exact test was used.

Multivariate analysis was carried out to determine the effect of TSH and anti - TPO Ab on percentage of live birth per individual. The covariates included for multivariate analysis were age, weight, TSH, anti-TPO titre, period of gestation and haemoglobin level of the patients. A p value of $<0.05$ was considered significant.

\section{RESULTS}

Out of 500 women, 407 women were anti-TPO $\mathrm{Ab}$ negative i.e. $81.4 \%$ (group A) and 93 women were found to be anti-TPO Ab positive. Thus, prevalence of anti-TPO $\mathrm{Ab}$ presence found to be $18.6 \%$ (group $\mathrm{B}$ ). Maximum patients were in the age group 25-29 years (54.3\%). Age had no significant association with anti-TPO Ab positivity (p-value 0.301 ). But as the age increased the odds of having anti-TPO Ab presence increased. Both the groups were comparable in age distribution.

In group $\mathrm{A}$ and $\mathrm{B}$, patients having no abortion were 373 $(91.6 \%)$ and $65(69.8 \%), 1$ abortion were $26(6.3 \%)$ and $13(13.9 \%), 2$ abortions were $7(1.7 \%)$ and $10(10.7 \%)$, $\geq 3$ abortions are $1(0.2 \%)$ and $5(5.3 \%)$ respectively. There was a statistically significant association between number of abortions and anti-TPO Ab positive status ( $\mathrm{p}-$ value $<0.001)$ and there was a significant correlation between these auto antibodies and number of abortions as depicted by the successive increase in odds ratio of having these auto antibodies as the number of abortions increase.

The prevalence of thyroid autoimmunity was higher in pregnant women with a history of recurrent abortion. There was no absolute difference in the prevalence of miscarriage between subclinical hypothyroid and euthyroid pregnant women irrespective of TPO status.

Table 1: Various adverse maternal occurrences in group $\mathbf{A}$ and group $\mathbf{B}$.

\begin{tabular}{|llll|}
\hline \multicolumn{1}{|c|}{$\begin{array}{c}\text { Anti-TPO A titre } \\
\text { complications }\end{array}$} & $\begin{array}{l}\text { Negative } \\
\text { N= 407 } \\
\text { group a }\end{array}$ & $\begin{array}{l}\text { Positive } \\
\text { N=93 } \\
\text { group b }\end{array}$ & $\begin{array}{l}\text { (chi- } \\
\text { square } \\
\text { test) }\end{array}$ \\
\hline No complication & $299(73.46 \%)$ & $55(59.14 \%)$ & 0.15 \\
\hline $\begin{array}{l}\text { H/o previous } \\
\text { abortion }\end{array}$ & $34(8.36 \%)$ & $28(30.11 \%)$ & $<0.001$ \\
\hline $\begin{array}{l}\text { Hypertensive } \\
\text { complications }\end{array}$ & $35(8.59 \%)$ & $19(20.44 \%)$ & 0.001 \\
\hline Preterm labour & $74(18.18 \%)$ & $48(51.62 \%)$ & $<0.001$ \\
\hline Gdm* & $0(0.00 \%)$ & $1.0(1.08 \%)$ & 0.01 \\
\hline Prom & $55(13.50 \%)$ & $16(17.20 \%)$ & 0.05 \\
\hline Aph* & $6.0(1.47 \%)$ & $4.0(4.30 \%)$ & 0.03 \\
\hline Postdatism & $60(14.74 \%)$ & $5.0(5.38 \%)$ & 0.25 \\
\hline
\end{tabular}

*As the cases were so small in number, even though p-value came out to be $<0.05$, so the results cannot be generalized on the entire population. $\mathrm{P}$ - value has been calculated by Fisher's Exact test.

When compared for maternal complications, in group B, $44 \%$ patients landed up in preterm delivery in comparison to only $8.3 \%$ patients in group A (p-value $<0.001)$. In group A and group B, $8.36 \%$ and $30.11 \%$ patients had history of previous abortions, $8.59 \%$ and $20.44 \%$ had hypertension or its complications, $18.18 \%$ and $51.62 \%$ patients had preterm labour, $13.5 \%$ and $17.20 \%$ patients had preterm premature rupture of membranes, $1.47 \%$ and $4.3 \%$ had antepartum haemorrhage, $0 \%$ and $1.08 \%$ had gestational diabetes mellitus respectively (Table 1). 
Table 2: Various adverse perinatal occurrences in group A and group B.

\begin{tabular}{|llll|}
\hline $\begin{array}{l}\text { Perinatal } \\
\text { outcome }\end{array}$ & $\begin{array}{l}\text { Anti - tpo ab titre } \\
\text { Negative } \\
\text { group A } \\
\mathbf{( 8 1 . 4 \% )}\end{array}$ & $\begin{array}{l}\text { Positive } \\
\text { group B } \\
\mathbf{( 1 8 . 6 \% )}\end{array}$ & $\begin{array}{l}\text { P-value } \\
\text { (chi } \\
\text { square } \\
\text { test) }\end{array}$ \\
\hline Prematurity & $74(18.18 \%)$ & $48(51.62 \%)$ & $<0.001$ \\
\hline IUD & $11(2.7 \%)$ & $19(20.43 \%)$ & $<0.001$ \\
\hline IUGR* & $2(0.49 \%)$ & $2(2.15 \%)$ & $<0.001$ \\
\hline LBW & $123(30.22 \%)$ & $51(54.84 \%)$ & $<0.001$ \\
\hline $\begin{array}{l}\text { Congenital } \\
\text { anomaly * }\end{array}$ & $0(0.00 \%)$ & $2(2.15 \%)$ & $<0.001$ \\
\hline $\begin{array}{l}\text { Need for NICU } \\
\text { admission }\end{array}$ & $73(17.94 \%)$ & $45(48.39 \%)$ & $<0.001$ \\
\hline *p-value calculated by Fisher's Exact test. & \\
\hline
\end{tabular}

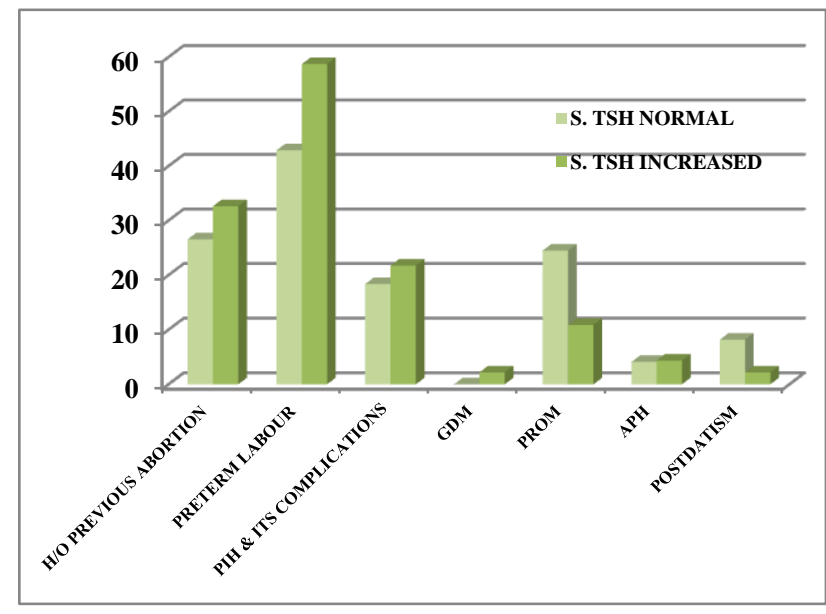

Figure 1: Distribution according to percentage of maternal complications based on serum TSH values.

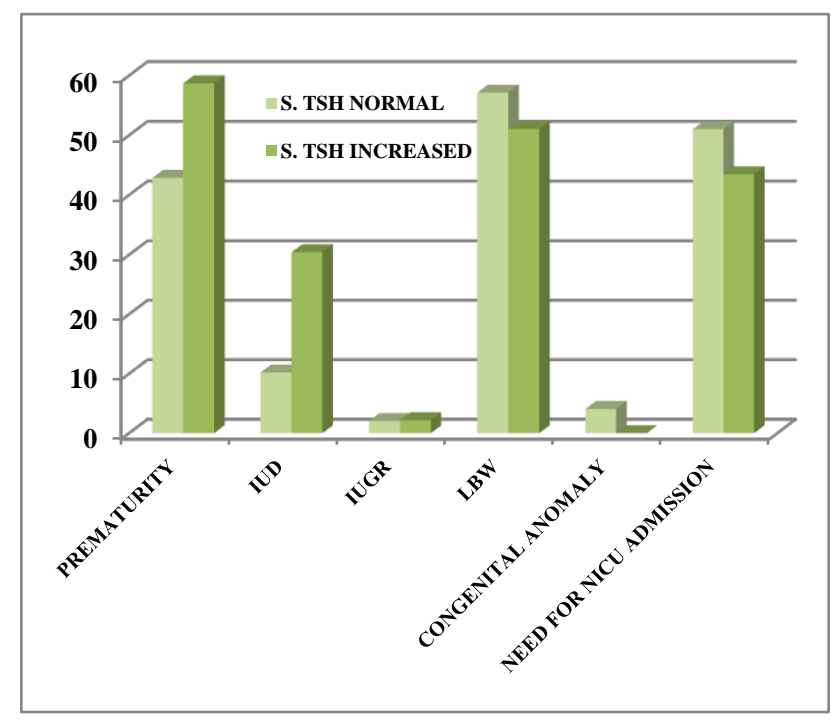

Figure 2: Distribution according to percentage of fetal complications based on serum TSH values.

When compared for perinatal complications, group A and group B, $18.18 \%$ and $51.62 \%$ were preterm neonates, $2.7 \%$ and $20.43 \%$ were intrauterine dead (IUD), $30.22 \%$ and $54.84 \%$ were low birth weight, $17.94 \%$ and $48.39 \%$ neonates needed neonatal intensive care unit (NICU) admission, $0.49 \%$ and $2.15 \%$ patients were intrauterine growth restricted (IUGR), $0 \%$ and $2.15 \%$ patients had congenital anomalies respectively (Table 2).

Serum TSH was done in group B only and $51.61 \%$ patients had normal TSH and $48.39 \%$ patients had raised TSH. Presence of Anti-TPO $\mathrm{Ab}$ had a significant association with raised serum TSH (p-value<0.001). Various maternal complications were comparable in both the groups having normal TSH and raised TSH (Figure1). Perinatal outcomes were also comparable in both the groups (Figure 2).

\section{DISCUSSION}

Autoimmune thyroid disease (AITD) is by far the most frequent cause of hypothyroidism in women of reproductive age. The prevalence of hypothyroidism in the general population of reproductive age is $\sim 2-3 \%$. This study was planned to study the prevalence of antiTPOAb in peripartum period and to correlate the prevalence of anti-TPO $\mathrm{Ab}$ with adverse pregnancy outcome.

In this study, prevalence of thyroid autoimmunity has been found to be $18.6 \%$. The national health and nutrition examination survey (NHANES) data from the USA reviewed in 2002, examining 17,353 people, showed $\mathrm{TPO}-\mathrm{Ab}$ in $13 \%$.

In this study, age had no significant association with antiTPO Ab positivity. But as the age increased the odds of having anti-TPO Ab positivity increased. In all the age groups of group A and group B the difference was statistically not significant ( $\mathrm{p}$ - value 0.301 ), and both the groups are comparable in age distribution.

A meta-analysis by Prummel et al showed that TPO Ab was associated with a twofold increased risk of miscarriage as shown in this study. ${ }^{11}$ Similar results were found by Negro et al who found the miscarriage rate in the TPO Ab group supplemented with levothyroxine 4 (T4) was comparable to healthy controls (3.5 versus $2.4 \%) .{ }^{12}$ Although multiple studies had demonstrated a risk of miscarriage in patients with AITD, the cause has yet to be established. TPO Ab is one of the markers of recurrent miscarriage. However, more evidence is needed before dismissing antibody positivity as a cause of adverse pregnancy outcome. The association of thyroid autoimmunity and miscarriage could be due to heightened autoimmune imbalance that in turn leads to a greater rejection rate of the foetal graft, and TPO Ab positive women would tend to become pregnant at an older age (3-4 years older on average), and older women are more prone to pregnancy loss. ${ }^{13,14}$

Women with hypothyroidism have decreased fertility, even if they conceive; the risk of miscarriage is increased. 
The risk of gestational hypertension, preeclampsia and eclampsia, abruption placentae, post-partum haemorrhage, premature delivery and IUGR is increased. ${ }^{14,15}$ These risks are increased in the whole spectrum of hypothyroidism, including isolated TPO positivity, subclinical hypothyroidism and overt hypothyroidism. In a study by Negro et al there was a positive association between thyroid autoimmunity with preterm delivery and neonatal respiratory distress syndrome in euthyroid women.

In this study anti-TPO $\mathrm{Ab}$ presence had a significant association with various maternal complications like preterm delivery, recurrent abortions, pre-eclampsia or its complications, antepartum haemorrhage, preterm rupture of membranes (p-value $<0.001$ ).

Various adverse perinatal outcomes had a significant association with anti TPO Ab positive status. Those who were positive for anti-TPO $\mathrm{Ab} 51.02 \%$ were premature, $20.43 \%$ were IUD, $54.84 \%$ were low birth weight $(<2.5$ $\mathrm{kg}$ ), $48.39 \%$ needed NICU admission, $2.15 \%$ were IUGR, $2.15 \%$ had congenital anomaly ( $\mathrm{p}$ - value $<0.001$ ).

A meta-analysis done in 2011 involving 30 articles with 31 studies (19 cohort and 12 case-control) involving 12,126 women assessed the association between thyroid auto antibodies and miscarriage. Five studies with 12,566 women evaluated the association with preterm birth. Of the 31 studies evaluating miscarriage, 28 showed a positive association between thyroid auto antibodies and miscarriage. Meta-analysis of the cohort studies showed more than tripling in the odds of miscarriage with the presence of thyroid auto antibodies (odds ratio 3.90, 95\% confidence interval 2.48 to $6.12 ; \mathrm{P}<0.001)$. For case control studies the odds ratio for miscarriage was 1.80 , 1.25 to $2.60 ; \mathrm{P}=0.002$ ). There was a significant doubling in the odds of preterm birth with the presence of thyroid auto antibodies $(2.07,1.17$ to $3.68 ; \mathrm{P}=0.01)$.

The frequent presence of thyroid auto antibodies in several non-thyroidal autoimmune diseases supports a hypothesis of global immune dysfunction being relevant to these clinical outcomes. ${ }^{16}$ There is evidence that there is an alteration in cytokine expression by peripheral $\mathrm{T}$ lymphocytes in women positive for thyroid antibodies outside of pregnancy. ${ }^{17}$ Pregnancy is an inflammatory process involving a shift in the regulation of cytokine networks within the local placental decidual environment.

Thyroid hormones can directly influence angiogenic growth factor and cytokine production as well as trophoblast proliferation, survival, and invasion. Furthermore, the presence of thyroid autoantibodies might be a marker of underlying subtle alteration in thyroid reserve which could be associated with reduced adaptation to the physiological changes of pregnancy and could contribute to minor changes in circulating thyroid hormone concentrations within the reference range. ${ }^{18}$

\section{CONCLUSION}

Pregnancy complicates both the physiology of the thyroid cell and the immune response to thyroid antigens. Thyroid auto antibodies are involved in both these areas and are associated with major alterations in the course of pregnancy affecting the mother, the fetus, and the neonate. Thyroid antibodies can serve as useful clinical predictors of thyroid dysfunction, for example, TPO Ab and post-partum thyroiditis and TSH receptor antibodies (TSHR-Abs) and neonatal hyperthyroidism. Our study has demonstrated that various adverse maternal and perinatal outcomes had a significant association with anti-TPO Ab positivity irrespective of serum TSH levels. So this antibody can be used as a surrogate marker of adverse pregnancy outcomes. Hence, screening in high risk group along with levothyroxine 4 (LT4) supplementation in future might prevent even some of these adverse perinatal occurrences.

\section{ACKNOWLEDGEMENTS}

The author wants to show heartfelt gratitude to all her patients without whose co-operation, the study would not have been possible and to the most benevolent without whose blessings, this work would have seemed impossible.

\section{Funding: No funding sources \\ Conflict of interest: None declared \\ Ethical approval: The study was approved by the Institutional Ethics Committee}

\section{REFERENCES}

1. McElduff A, Morris J. Thyroid function tests and thyroid autoantibodies in an unselected population of women undergoing first trimester screening for aneuploidy. Aust NZJ Obstet Gynaecol. 2008;48:478-80.

2. Stagnaro-Green A, Roman SH, Cobin RH, el-Harazy E, Alvarez-Marfany M, Davies TF. Detection of atrisk pregnancy by means of highly sensitive assays for thyroid autoantibodies. JAMA. 1990;264:1422-5.

3. Casey BM, Dashe JS, Wells CE, Mclntire DD, Byrd W, Leveno KJ, et al. Subclinical hypothyroidism and pregnancy outcomes. Obstet Gynecol. 2005;105:23945.

4. Casey BM, Dashe JS, Spong CY, Mclntire DD, Leveno KJ, Cunningham GF. Perinatal significance of isolated maternal hypothyroxinemia identified in the first half of pregnancy. Obstet Gynecol. 2007;109:1129-35.

5. Barber WA, Fernando M, Chadwick DR. Plasma cell granuloma of the thyroid: a conservative approach to a rare condition and review of the literature. J Thyroid Res, 2010. Available at http://www.sagehindawi.com/journals/jtr/2010/840469.html. Accessed on 15 June 2015. 
6. Cleary-Goldman J, Malone FD, Lambert-Messerlian G, Sullivan L, Canick J, Porter TF, et al. Maternal thyroid hypofunction and outcome. Obstet Gynecol. 2008;112:85-92.

7. Haddow JE, Palomaki GE, Allan WC, Williams JR, Knight GJ, Gagnon J, et al. Maternal thyroid deficiency during pregnancy and subsequent neuropsychologilcal development of the child. N Engl J Med. 1999;341:549-55.

8. Pop VJ, Kuijpens JL, van Baar AL, Verkerk G, van Son MM, de Vijlder JJ, et al. Low maternal free thyroxine concentrations during early pregnancy are associated with impaired psychomotor development in infancy. Clin Endocrinol (Oxf). 1999;50:149-55.

9. Pop VJ, Brouwers EP, Vader HL, Vulsma T, van Baar AL, de Vijlder JJ. Maternal hypothyroxinemia during early pregnancy and subsequent child development: a 3-year follow-up study. Clin Endocrinol (Oxf). 2003;59:282-8.

10. Kuijpens JL, De Hann-Meulman M, Vader HL, Pop VJ, Wiersinga WM, Drexhage HA. Cell-mediated immunity and postpartum thyroid dysfunction: a possibility for the prediction of the disease? J Clin Endocrinol Metab. 1998;83:1959-66.

11. Negro R, Formoso G, Mangieri T, Pezzarossa A, Dazzi D, Hassan H. Levothyroxine treatment in euthyroid pregnant women with autoimmune thyroid disease: effects on obstetrical complications. J Clin Endocrinil Metab. 2006;91:2587-91.

12. Poppe K, Glinoer D. Thyroid autoimmunity and hypothyroidism before and during pregnancy. Hum Reprod Update. 2003;9:149-61.
13. Glinoer D, de Nayer P, Bourdoux P, Lemone M, Robyn C, van Steirteghem A, et al. Regulation of maternal thyroid during pregnancy. The Journal of Clinical Endocrinology and Metabolism. 1990;71(2):276-87.

14. Stagnaro-Green A, Roman SH, Cobin RH, El-Harazy E, Alvarez-Marfany A, Davies TF. Detection of atrisk pregnancy by means of highly sensitive assays for thyroid autoantibodies. Journal of the American Medical Association. 1990;264(11):1422-5.

15. Prummel MF, Wiersinga WM. Thyroid autoimmunity and miscarriage. European Journal of Endocrinology. 2004;150(6):751-5.

16. Glinoer D, Soto MF, Bourdoux P, Lejeune B, Delange F, Lemone $\mathrm{M}$, et al. Pregnancy in patients with mild thyroid abnormalities: maternal and neonatal repercussions. Journal of Clinical Endocrinology and Metabolism. 1991;73(2):421-7.

17. Nakamura $\mathrm{H}$, Usa $\mathrm{T}$, Motomura $\mathrm{M}$, Ichikawa $\mathrm{T}$, Nakao K, Kawasaki E, et al. Prevalence of interrelated autoantibodies in thyroid diseases and autoimmune disorders. J Endocrinol Invest. 2008;31:8615.

18. Challis JR, Lockwood CJ, Myatt L, Norman JE, Strauss JF, Petraglia F. Inflammation and pregnancy. Reprod Sci. 2009;16:206-15.

19. Glinoer D. Miscarriage in women with positive anti TPO antibodies: is thyroxine the answer? J Clin Endocrinol Metab. 2006;91:250-2.

Cite this article as: Gupta A, Wajdi N, Verma A, Pal MK. Role of anti-thyroid peroxidase antibodies in adverse pregnancy outcomes. Int J Reprod Contracept Obstet Gynecol 2016;5:3001-5. 